\title{
Canine Soft Tissue Sarcoma
}

National Cancer Institute

\section{Source}

National Cancer Institute. Canine Soft Tissue Sarcoma. NCI Thesaurus. Code C132276.

Soft tissue sarcoma occurring in a dog. 